\title{
1603
}

THE ROLE OF PASSENGER LEUKOCYTES IN REJECTION AND

"TOLERANCE" AFTER SOLID ORGAN TRANSPLANTATION: A POTENTIAL

EXPLANATION OF A PARADOX

Anthony J. Demetris ${ }^{1}$, M.D.

Noriko Murase ${ }^{2}$, M.D.

Abdul S. Raol, 2, M.D., D. Phil.

Thomas E. Starzl ${ }^{2}$, M.D., Ph.D.

From the Pittsburgh Transplant Institute, Departments of

Pathology ${ }^{1}$ and Surgery ${ }^{2}$, University of Pittsburgh Medical

Center, Pittsburgh, Pennsylvania, 15213.

Aided by Project Grant No. DK 29961 from the National

Institutes of Health, Bethesda, Maryland.

Address correspondence to: Thomas E. Starzl, M.D., Ph.D.,

3601 Fifth Avenue, 5C Falk Clinic, University of Pittsburgh,

Pittsburgh, Pennsylvania, 15213 .

325

J. L. Touraine et al. (eds.), Rejection and Tolerance, 325-392.

(C) 1994 Kluwer Academic Publishers. Printed in the Netherlands. 
The concept that passenger leukocytes are more "immunogenic" and thus initiate rejection, which is ultimately directed against the parenchyma and vessels of solid organ allografts, was first proposed by Snell (1) and later proved by Steinmuller (2). Steinman and Cohn (3-6) subsequently showed that a distinct type of passenger leukocyte, the dendritic cell, provides the most potent of the allogeneic stimuli. Besides dendritic cells, which reside in the interstitium of all allografts, every organ also carries with it a variable number of $T$ and $B$ lymphocytes, macrophages and myeloid cells. Therefore, each type of allograft presents a heterogenous stimulatory profile as well as the potential for graft-versus-host (GVH) reactions.

Based on the seemingly logical assumption that the highly immunogenic passenger leukocytes are deleterious to graft survival, attempts have been made to deplete donor hematolymphoid cells from organs prior to transplantation (7-10). While this approach can clearly yield improved short-term results, leukocyte-depleted allografts are still eventually rejected. Even epidermal allografts, which consist of pure keratinocyte cultures are rejected (11). 
In a seeming paradox, donor hematolymphoid cells, particularly those from the bone marrow, are known to carry with them the ability to render the recipient's immune system specifically unresponsive to subsequent organ allografts (12-19). Owen (20) was the first to show that cattle fetuses whose individual placentas had placental cross-circulation (freemartins) subsequently developed "chimeric" hematolymphoid systems. The chimerism, which was a mixture of the $A B O$ (and presumably other) phenotypes of the fetuses persisted, for a lifetime and was associated with subsequent cross-tolerance to tissue and whole organ (kidney) grafts (21).

The lead provided by Owen caused Burnet and Fenner (22) to predict the feasibility of iatrogenetically producing acquired tolerance by exposing fetuses to immunologically active adult tissues in utero, and this feat was accomplished in 1953 with spleen cells in mice by Billingham, Brent, and Medawar $(12,23)$ in what was a decisive stimulus toward the ultimate development of clinical transplantation. Ensuing experimental models of radiation and monoclonal antibody-induced mixed hematolymphoid chimeras in adults are based on this principle. In general, these models attempt to recapitulate development of the neonatal immune system in a "twin-like" environment. First, the recipient's immune system is disabled with drugs or radiation, which is followed by an 
infusion of donor hematolymphoid cells. In this paradigm, uncommitted stem cells which have seeded the bone marrow, produce progeny that are educated in the recipient's thymus and immune system. Eventually, tolerance to a subsequent solid organ allograft is produced, but how this occurs is poorly understood.

Although Owen's original observations in freemartin cattle were of mixed chimerism, as opposed to the full chimerism of the Billingham-Brent-Medawar model, this crucial difference was seldom emphasized. The association of acquired tolerance with full chimerism, meaning complete replacement of the host hematolymphopoietic system with that of the donor, was so strong following the Billingham-BrentMedawar reports that stable and permanent mixed chimerism as a means of tolerance induction was rarely mentioned again for almost 4 decades. In fact, hematolymphopoietic replacement was the dogma by which bone marrow transplantation per se was developed experimentally and ultimately used clinically $(24,25)$. This approach was long envisioned to be the potential means by which tolerance could be induced for whole organ grafts (13).

Using the total bone marrow conditioning approach, permanent tolerance to a variety of organs has been produced across partial and full MHC, and even across species barriers (13-19). However, there were two major drawbacks 
which prevented clinical application. One was that the conditioning regimens necessary to ensure donor bone marrow engraftment were extreme, with an inherent short-and longterm morbidity. The second and more fundamental problem first described by Billingham and Brent (26) in mice was the development of graft versus host disease (GVHD). The risk from this complication in which the new immunologic apparatus destroyed the host was directly related to the degree of histoincompatibility between donor and recipient (27), restricting the marrow or other similar conditioning strategies to patients with perfect MHC-matched donors $(24,25,28,29)$.

The entrenchment and durability of this therapeutic doctrine as a rational approach to tolerance induction for whole organs is really quite remarkable in view of the obvious fact that it was not fundamentally feasible. In the meanwhile, an important but long unexploited experimental observation by Liegeois et al $(30,31)$ suggested as early as 1974 that complete extirpation and replacement of the recipient hematolymphopoetic system was not an absolute requirement for engraftment of donor bone marrow and the consequent induction of tolerance for other donor tissues and organs. These investigations were performed in Paris in an attempt to explain donor specific nonreactivity to skin grafts induced first by Monaco, Wood, and Russell (32) and then by Wood, Monaco, Gozzo, and Liegeois (33) with 
antilymphocyte serum (ALS) plus delayed intravenous bone marrow infusion one week later. Using karyotyping techniques, Liegeois et al $(30,31)$ demonstrated progressively declining (always small) numbers of replicating donor bone marrow cells in the recipient's spleens as long as 134 days after the bone marrow-skin transplantations, a condition which they termed microchimerism. Although Liegeois et al $(30,31)$ and Monaco (34) were intrigued by this finding, their assumption and that of others was that the decline in identifiable donor cells was premonitory to their extinction. This point of view that these chimeric cells were transient, prevented the recognition of the full significance of Liegeois's findings. In addition, these findings following bone marrow infusion were not suspected to pertain also to passenger leukocytes from whole organs.

In principle, slavin and Strober et al (14-16) showed the same thing as Liegeois in 1977, but with the additional information that the mixed microchimerism could be persistent and stable for long periods. In rats treated with total lymphoid (not total body) irradiation (TLI) and donor bone marrow infusion, they produced mixed chimerism, emphasized the lack of GVHD in their animals, and showed that the donor and recipient were reciprocally tolerant -.. analogous to Owens' freemartin cattle (20). Subsequently, Ildstad and Sachs (17) provided convincing confirmation by 
cytoablating recipients and reconstituting them with mixed donor and recipient marrow, with consequent mixed allogeneic or xenogeneic chimerism. Slavin and Strober's experiments led to clinical trials of kidney and liver transplantation with donor bone marrow augmentation more than a decade ago (35-42), but these were abandoned because of the conviction that the bone marrow was an unnecessary adjuvant to the TLI, and was potentially harmful (38-42).

Nearly a decade after the reports by Billingham, Brent, and Medawar $(12,23)$, a seemingly different therapeutic dogma was developed with continuous chemical immunosuppression that allowed increasingly successful whole organ transplantation with graft acceptance by what were widely construed as different immunologic mechanisms (44-51). This misconception was dispelled in 1992 with the demonstration that long-surviving human kidney, liver, and other whole organ recipients had low level mixed allogeneic chimerism (52-57) from dissemination and survival of passenger leukocytes leaving the graft. The pattern and time course of the cell migration and the movement into the graft of recipient cells of the same lineages could be easily identified after liver transplantation in experimental animals $(58,59)$. This was a mechanism that defied the logic of the diametrically opposite strategy of trying to deplete the passenger leukocytes described in the introduction of this article. 


\section{Definition of a Paradox}

Although donor hematolymphoid cells have been identified both as the most immunogenic (1-11) and the most tolerogenic cells (12-19) associated with solid organ allografts, there have been few attempts until recently to reconcile these apparently paradoxical roles. One reason apparently has been the assumption that the passenger leukocytes transferred with a solid organ were fundamentally different from those found in the bone marrow. In addition, many investigators have also assumed that the number of transferred donor hematolymphoid cells was insignificant and the cells were rapidly destroyed. The recent studies in humans and experimental animals have shown that both of these assumptions were invalid (52-59). In fact, we have proposed that persistence of rare passenger leukocytes in recipient tissues is conducive to, and the explanation of, graft acceptance. Properly addressing this opposite effect paradox may yield a different perspective of transplantation biology.

The following is not intended as a review of the area of passenger leukocytes in transplantation biology. Rather this manuscript should be considered as a hypothesis to explain how donor hematolymphoid cells transferred with the graft could assist in graft acceptance. A brief description 
of the their role in provoking rejection and tolerization is also presented. This aspect is particularly important to development of the hypothesis.

\section{Passenger Leukocytes Under Temporary Immunosuppression or in Untreated Organ Allograft Recipients}

The Liver --- The early events leading to the chimeric state after liver transplantation have been studied in rats (58) and mice (59), including the pathways of passenger leukocyte dissemination. Within minutes or hours, some of these cells leave the liver and home to the spleen, lymph nodes, thymus, and bone marrow where they are destroyed by rejection in most animals models except those using mice as

subjects. However, under temporary immunosuppression in rats ( 2 weeks daily FK 506), these mononuclear cells pause for about 2 weeks in the lymphoid organs, but then break out and move secondarily to all recipient tissues (58). Rat liver recipients treated in this way (for example, Lewis [LEW] to Brown Norway [BN]) survive indefinitely without further treatment and retain their graft and systemic chimerism.

Interestingly, permanent survival of the engrafted livers occurs without any immunosuppression in some rat strain combinations of which BN to LEW has been most 
completely studied (60), and it occurs without treatment in virtually all mouse strain combinations no matter how severe the histoincompatibility (59). The heavy endowment of the liver with potentially migratory white cells is thought to be the basis for the previously inexplicable phenomenon of "hepatic tolerogenicity".

In fact, we believe that the foregoing migration and repopulation is the central mechanism of acceptance of all whole organ grafts (52-59). Although this is a generic process, there are quantitative differences between organs in the density of the potentially migratory dendritic cells, macrophages, and lymphoid collections. The heavy endowment of the liver with the foregoing leukocyte lineages (including Kupffer cells) is a particularly striking feature that invites further speculation about the role of these cells in the well known tolerogenicity of this organ.

The immunologic advantage of the liver relative to other organs includes a greater ease of inducing the acceptance of hepatic allografts (described above) or xenografts after a limited course of immunosuppression $(47,49,61,62)$ or in swine $(63-65)$ and some rat strain combinations $(60,66)$ with no treatment at all. In addition, the transplanted liver graft is relatively resistant to the preformed antigraft antibodies that cause hyperacute rejection of the kidney and heart (67-70). Another quality 
is its unusual ability to induce a state of unresponsiveness to other tissues and organs transplanted concomitantly or subsequently from the donor or donor strain $(66,68,71)$ and even shield these organs from the hyperacute rejection caused by preformed allospecific (70) or xenospecific (72) antidonor antibodies. In all of these circumstances, the liver appears to quickly transform the recipient environment to one more favorable for all donor tissues including itself. All of these qualities of the liver are evident in practically every mouse strain combination, no matter what the degree of histoincompatibility (59).

other Organs --- The foregoing observations have been attributed to "hepatic tolerogenicity", incorrectly we believe, because the term implies that the hepatocytes are responsible. We have proposed that the crucial variable distinguishing the tolerogenicity of one organ graft from another under effective immunosuppression (or in some animal models without treatment) is its leukocyte, not its parenchymal component (56-59). This is a reversal of the immunogenic role described classically for the "passenger" white cells $(1-10,73-76)$. Thus, because of its dense constituency of these migratory leukocytes, the liver is high on the favorable tolerogenic list with the lung and intestine following and the kidney and heart bringing up the rear. Experimental studies showing less striking tolerogenicity of the lymphoreticular-rich spleen (77-79), 
intestine (80), and lung $(81,82)$ are compatible with this generalization.

\section{Sites of Alloactivation and Tolerization} with Particular Reference to Leukocyte-Poor Organs

By the end of 1992, it was concluded that all whole organs underwent the same process of potential tolerance induction as the liver, although the dynamics were not so easy to study except with the leukocyte-rich intestine $(80,83-85)$. However, the same kind of traffic in the context of alloactivation and rejection rather than tolerization, had been well worked out earlier with the socalled lymphoid-poor organs including the kidney. studies in untreated animals have shown that the alloreaction starts in 2 general sites, peripherally in the graft and centrally in the recipient lymphoid tissues.

Central Alloactivation -- In a very complete study in 1981 of untreated rat kidney recipients, Hayry and Nemlander and their associates (86) demonstrated extensive leukocyte migration to the spleen and elsewhere. If Hayry had given one or two doses of cyclosporine in his kidney transplantation experiments (which were with an "easy" strain combination) and had followed his animals further, he almost certainly would have uncovered the events of cell migration and long term repopulation that awaited another 
dozen years for exposure with the liver (58). Larsen et al (87) found that donor dendritic cells from heterotopic cardiac allografts were released into the circulation, where they eventually homed into the $\mathrm{T}$-cell areas of the recipient spleen. In the spleen, the donor cells initiate proliferation of recipient cells, and vice versa (86-90). This reaction might be thought of as an in vivo mixed lymphocyte response (MLR) and epitomizes central allosensitization with potential tolerization.

Intragraft Alloactivation -- Allosensitization (and tolerization) presumably also occurs within the graft. Forbes et al (89) showed that clustering of recipient lymphocytes occurs around donor dendritic cells in the interstitium of cardiac grafts, within a few days after transplantation. The recipient lymphoid cells were undergoing blastogenesis and proliferation in these clusters. We have described analogous events in rejecting rat livers (88).

In human recipients of kidney grafts $(91,92)$ under cyclosporine-prednisone immunosuppression, Hayry and Willebrand noted what appeared to be a bidirectional MLR in needle aspiration biopsies. When studied with the Staphylococcus aureus assay and alloantibodies to non-shared donor and recipient allelic specificities, most of the collected blast cells in some cases were derived from the 
donor or else the response was split, "resembling a

bidirectional mixed lymphocyte reaction in vitro" (91).

In these models, the difference from the experiments

with liver transplantation appear to be quantitative. With the smaller number of passenger leukocytes, there is a greater tendency to allosensitization and less to tolerogenicity. Nevertheless, Corry (93) and Russell et al (94) showed that tolerance without drug induction could be induced by heart and kidney transplantation between weakly MHC incompatible strains of mouse recipients.

The Parking Experiments - - Earlier evidence that the disseminated passenger leukocytes play a crucial role in allograft rejection came from elegant studies by Lechler and Batchelor $(75,76)$, who demonstrated that rat allogeneic kidneys were indefinitely accepted if they were first "parked" in the immunosuppressed recipient and subsequently re-transplanted secondarily into naive animals syngeneic to the recipient strain $(75,76)$. However, these kidneys were acutely rejected if the animals receiving the re-transplants were intravenously injected with donor strain dendritic cells (76). This was the first direct evidence that the immunogenecity of a passenger cell depleted allograft and could be restored by addition of donor strain dendritic cells. Similar observations were also made by Benson et al, (95) who showed that deoxyguanosine treated fetal thymus 
allografts were rejected if transplanted into animals primed with donor-strain dendritic cells.

Unfortunately, results with the experimentally useful parking model have been extrapolated overly freely to discussions and criticisms of the cell migration and microchimerism concepts. In the parking experiment, neither the host immunocytes (including those that home to the parked organ) nor the donor leukocytes seeded ubiquitously in the recipient remain the same. The changes have been shown dramatically in rat liver transplant experiments in which the "passenger leukocyte" load brought in with the liver was augmented by donor bone marrow simultaneously or at an earlier time. Staged delivery of the donor leukocytes caused fulminant GVHD. Aside from clarifying limitations in interpretation of parking experiments, these studies have significant clinical implications in planning the staged use of bone marrow for the augmentation of passenger leukocytes (58) .

\section{The Fate of Passenger Leukocytes in Treated Recipients}

Immunosuppressive drugs such as FK 506 do not grossly

alter the migration of donor hematolymphoid cells out of an allograft $(58,96,97)$. However, almost all immunosuppressants markedly reduce the infiltration of recipient cells into the graft. They also protect the graft 
from injury and prolong the survival of donor passenger leukocytes, both within the graft and peripherally in the recipient tissues $(58,96,97)$. Additionally, neither FK 506 nor cyclosporine abolish the immune response in recipient's lymphoid tissues provoked by the passenger leukocytes $(58,98,99)$. They merely diminish it, and possibly alter the response in a qualitative fashion $(58,98,99)$.

Over time, the peripheralized donor cells can be identified in the recipient's skin, visceral organs and lymphoid tissues, including the bone marrow and thymus $(58,97)$. This ubiquitous distribution argues against passive spread via draining lymphatics. Moreover, homing of the donor cells to the same anatomic locations as their phenotypically identical counterparts argues for the existence of preprogrammed migratory routes, which are independent of allogeneic barriers (99-102). Thus, immunosuppressive drugs regardless of their molecular site of action, appear to have a permissive and regulatory, rather than a purely inhibitory effect on the interactions between donor and recipient hematolymphoid cells $(56,58)$.

Even under the protection of continuous immunosuppression, the number of donor cells that have emigrated out of transplanted organs gradually decreases with time $(58,59)$. One likely explanation for this finding is that the majority of the transferred donor cells have a 
mature phenotype, and therefore are eventually eliminated by the recipient's immune system. Or if they are terminally differentiated and are incapable of further division, they simply die out. Finally, it is possible that a few donor progenitor cells "engraft" and produce a very small number of peripheralized donor cells, which can persist for many years in the tissues of stable organ allograft recipients.

To designate this condition, we have used the term "micro-chimerism" that was originally coined by Liegeois et al $(30,31)$ and popularized by Monaco (34). If, however, "microchimerism" is of importance in tolerance, any hypothesis explaining the mechanisms must account for an effect of the donor cells, which far exceeds their number $(52-59)$.

Macro- versus Microchimerism

Because these 2 terms have been used in different ways, it is important for this discussion to define our meaning. It is generally accepted that stable hematolymphoid macrochimerism is synonymous with allogeneic tolerance. Radiation models, such as those described by Ildstad and Sachs (17) and the human fetal-liver recipients described by Touraine (103), have defined mixed hematopoietic macrochimerism using flow cytometric studies. This technology can confidently discriminate between allogeneic 
populations when one component is as small as $1.0 \%$. Although, individual contributions to the total pool reciprocally may vary between 10 and 90 percent, hematopoietic cell lineages from both donor and recipient can usually be detected.

In vitro immunologic testing in the mouse models of macrochimerism reveals a donor specific proliferative defect and lack of donor-directed cytolytic activity, while the same responses to third party lymphocytes remain intact (17). This in vitro state of nonreactivity may not be absolute in higher species. For example, the human macrochimeras reported by Touraine and Roncarolo et al (103) show host reactive cells in vitro. Yet, such patients have no obvious GVHD and the donor cells appear to be under a regulatory influence, perhaps mediated by cytokines or other cells.

In a different context, Thomas et al have used the word microchimerism to describe nodules of donor leukocytes found on the capsule of renal allografts in subhuman primates rendered donor specific tolerant by adjuvant bone marrow infusion and ALG plus total lymphoid irradiation (104).

"Microchimerism" as reported by us in humans (52-57) and in animals $(58,59)$ refers to the diffuse rather than localized presence in recipient tissues of donor cells at 
levels below the detection threshold of flow cytometry, thus requiring alternative methods of identification (52-59). Donor cell labeling using immunocytochemistry with anti-MHC monoclonal antibodies or in situ hybridization for mismatched sex chromosomes can detect donor cells present in recipient tissues in concentrations between 1:1000 and 1:5000. Polymerase chain reaction studies for mismatched HLA-DR alleles or the $Y$ chromosome is even more sensitive. As few as one cell in 40,000 can be identified.

Because of the paucity of cells present in microchimerics, it is difficult to define multiple lineages in a single stable patient. However, multilineage chimerism has been shown in several humans (105-107) after liver transplantation. In rat and mouse studies $(58,59)$, different lineages are found as long as 300 days after transplantation.

In vitro immunologic testing of "microchimeras" may show donor specific hyporeactivity, but intact MLR and CML responses may also be seen $(49,59,104,108,109)$. This is not surprising, since Strelein et al (110) has shown before in neonatal chimeras, that in vitro immunologic testing may not always reflect, or predict, in vivo tolerance. No matter what the outcome of in vitro assays, recipients often tolerate allografts in vivo in the same way as the 
macrochimeric recipients cited above

$(49,59,104,108,109,111)$.

\title{
The Commonality of Treatment Regimens to Induce Chimerism and Tolerance in Adults
}

\begin{abstract}
Regimens used to induce allogeneic tolerance in the adult animal (or in humans) have in common two factors, donor allo-antigen, which is a specific requirement, and non-specific immunosuppression for variable periods (13-19). With the possible exception of the liver (59), donor bone marrow has been the best source of "tolerogenic alloantigen". The best choice of immunosuppression remains controversial, but virtually all potent modalities achieve the same end result in spite of their widely variable mechanisms. For example, cytotoxic drugs that inhibit DNA synthesis, cyclosporine, FK 506, monoclonal antibodies, radiation, cytokine therapy, or nothing at all except donor tissue have all been used to induce tolerance with variable success $(13-19,52-59)$.
\end{abstract}

A very important concept that emerges in the development of all of these regimens is that too much immunosuppression can block the induction of tolerance (112), implying that it is an active process. Wood et al (112) and Liegeois et al $(30,31)$ have particularly emphasized this point as well as the dynamic nature of 
tolerance. It is also known that the dose and timing of alloantigen presentation influences the final outcome of tolerance induction $(13-19,30,31,52-59)$. These considerations are not different from those required to induce tolerance to self or other non-allogeneic antigens $(106,113,114)$.

Because of the passenger leukocyte migration and repopulation that now are known to be a generic phenomena after the engraftment of all whole organs, every such clinical operation has the theoretic potential for initiating tolerance induction. However, this does not happen reliably, and despite the co-existence of both alloantigen and immunosuppression, drug-free graft acceptance is an uncommon clinical outcome. Nevertheless, the ability to eventually withdraw immunosuppressive drugs without initiating graft rejection has often been documented in clinical reports, particularly after liver transplantation $(57,115)$, and can be routinely accomplished in numerous experimental transplantation models $(58,59)$. Drug withdrawal is least often achieved without complications in kidney and heart allograft recipients (57).

One obvious difference between these organs is the number of passenger leukocytes, which is higher in the bone marrow and liver than in heart or kidney. However, in the ensuing paragraphs, we will first globally and then 
specifically attempt to describe how the presence of donor leukocytes, even in small numbers, can promote allograft acceptance. Our hypothesis is based on a network viewpoint of the immune system (116-123).

\section{Global Hypothesis}

Transplantation of a solid organ without the need for continual immunosuppression requires in some respect, redefinition of the recipient's immunologic self (116). Cotransplantation of a fragment of the donor's immune system (i.e., passenger leukocytes of solid organ grafts, or bone marrow augmentation), whose normal function is to define the donor's immunologic self, would appear to be most capable of achieving this task (116-117). In fact, the desire to induce hematolymphoid chimerism for promoting allograft acceptance is knowingly or unknowingly, based on this idea and in essence, is an attempt to merge two different immune systems.

This merger however is resisted by mature cells in both immune networks, which mediate classical alloimmune reactions and NK cells, which can prevent allogeneic progenitor cell engraftment $(124,125)$. Any maneuver that results in the combination of less immunogenic and more plastic donor and recipient hematolymphoid progenitor cell populations lessens the resistance. Therefore, most 
investigators have used depletion of mature cells from the donor inoculum and ablation of donor reactivity in the recipient by cytoreductive or radiation therapy (13-19). It is now realized that transplant surgeons have been unknowingly protecting the passenger leukocyte (donor immune system) by various forms of immunosuppression while it carried out immunologic redefinition of the recipient (5257) .

The concept of MHC restriction however, appears to limit the interactions that could occur between allogeneic lymphoid cells to antagonistic ones. But, if these engagements are viewed as receptor-ligand interactions of varying "fits" or affinities, the possibility of cooperative interactions occurring between allogeneic cells is not unreasonable (116-123). In fact, effective collaboration between allogeneic APC's and lymphocytes within a single chimeric immune network has been shown before in a chimeric human (103). "Cross-talk" between the allogeneic cells of both populations comprising a fully integrated chimeric immune system is the ultimate goal.

The key component for establishing and maintaining tolerance in a chimeric allogeneic network would be donor cells or antigen if immunologic self definition is maintained by self assertion as Coutinho suggests (116). This requirement for the presence of the tolerated antigen 
is not different from that of classical explanations of allogeneic tolerance $(114,126-128)$. The major difference between these two views turns on whether tolerance is an active or passive process. Under either circumstance, the donor cells provide the necessary signals to imprint specificity and inhibit the development of effector responses $(112,114,126)$.

From this viewpoint, it becomes very difficult to dispute that hematopoietic chimerism is essential for successful organ engraftment, whether this is at a macro or micro level. The direct relation of acquired tolerance (and GVHD) with chimerism discovered by Billingham, Brent and Medawar $(12,23)$ was formally verified by Russell (129) who reversed both tolerance and -.- runt disease (GVHD) with the elimination of the chimerism with antidonor leukocyte antibodies. The only debate is the quantity of donor leukocytes required. This may be a moot point if the iterative and metadynamic properties of an immune network. are considered (116-123). The mobile donor hematolymphoid cells released from the graft during the first week or so after transplantation provoke an initial burst of alloreactivity in the recipient's lymphoid tissue. Under the protection of immunosuppression they also begin to participate alongside recipient cells in preprogrammed migratory routes (e.g. through the thymus and lymphoid tissues) $(58,97)$. Exposure of immature recipient cells to 
donor dendritic and other leukocyte populations during thymic or early post-thymic maturation gradually erodes the basis for alloreactivity and the singular identity of the recipient's "immunologic self".

The education or re-education process is made easier if the merging populations consist of relatively immature and more malleable uncommitted progenitor cells, like those seen in neonates. Such cells have more ready access to "immunologic privileged" sites such as the thymus and spleen and serve as a renewable source of cells. However, regardless of their age, mixing of allogeneic hematolymphoid populations would eventually exert selection pressures on various receptor specificities, such that evolution of the chimeric mixture would occur. Genetic restriction of receptor configurations may ultimately determine whether a dynamic equilibrium is ever reached (116-123).

\section{MECHANISTIC HYPOTHESIS}

A network-based viewpoint categorizes immune responses as receptor-ligand interactions, occurring between the receptors on various participating cellular populations (116-123). For example, CD4+ $T$ cells are originally selected in the thymus on the basis of their affinity for self-MHC class II antigens, that are expressed on the surface of antigen presenting cells(APC) $(130,131)$. Cells 
with an extremely high or low affinity or "fit" for self MHC class II are negatively selected and therefore not represented in the peripheral $\mathrm{T}$ cell pool. Cells with receptors of intermediate affinity are positively selected on the basis of limited "autoreactivity (anti-self class II)", and released from the thymus to participate in immune responses.

In the periphery, alterations of self-MHC class II on an APC, induced by binding of an exogenous peptide, changes the affinity of these cells for receptors on $\mathrm{CD} 4+\mathrm{T}$ cells, which in turn results in $\mathrm{T}$ cell activation (132-134). The activated $\mathrm{CD} 4+\mathrm{T}$ cells then develop idiotypes that are antigenic to a subgroup of anti-idiotypic regulatory $\mathrm{T}$ cells. The regulatory cells are thought to recognize the class II MHC/T-cell receptor complex present on the activated $\mathrm{CD} 4+\mathrm{T}$ cells (anti-anti-self) (Figure 1) and thereby prevent uncontrolled autoreactivity. The anti-anti self MHC class II/receptor on the regulatory T-cells resemble the self-MHC class II antigens present on the original stimulatory APC's, and because of this have been called "MHC-image" (MHCi) cells $(119,120)$. Such cells have been identified during and after exposure to toxins, nominal antigens and graft-versus-host and allogeneic reactions (135-142). We would suggest however, that antibodies also could provide an MHCi, and function with the regulatory $\mathrm{MHCi}$ cells in a "suppressor-like" fashion, showing high network 
Figure 1. Diagrammatic presentation of the theory of "Network Focusing".

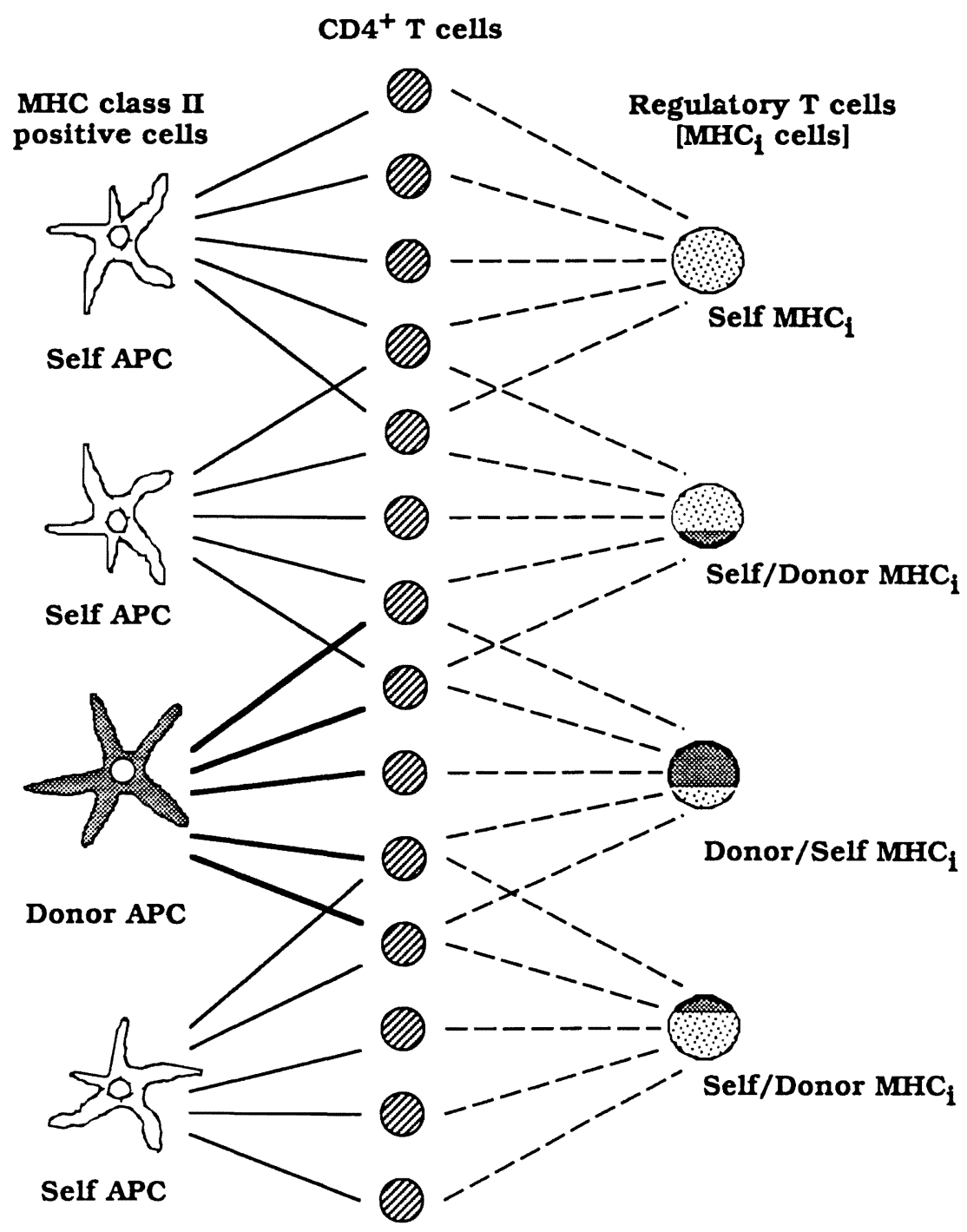


connectivity (i.e few cells would regulate many others) (116-123). The entire concept is illustrated in Figure 1 has been referred to as "network focusing" $(119,120)$.

We propose that an alloreaction is not fundamentally different from other immune responses. It is subject to similar regulatory controls. In fact, the essence of our hypothesis is that the alloreaction itself gives birth to the tolerogenic cells by imprinting on the recipient's immune network an internal image of the donor. Furthermore, allogeneic tolerance is maintained by specific autoimmune reactions, which are fueled by the presence of donor hematolymphoid cells(Figure 2). Over time the continued participation of donor cells in the recipient's immune network gradually erodes the previously strong barriers that prevent effective cooperation between allogeneic networks $(58,143)$. The following paragraphs describe how this could occur.

Spontaneously alloreactive $\mathrm{T}$ cells comprise about $1 \%$ of the total peripheral $\mathrm{T}$ cell pool, and have been shown to crossreact with self-APC bearing a nominal antigen (132134). Because of this crossreactivity, an immune network would likely be unable to reliably distinguish between an alloreaction and response to other antigens (132-134). However in an alloresponse, the MHCi cells are selectively stimulated on the basis of receptor complementarity to 
a)

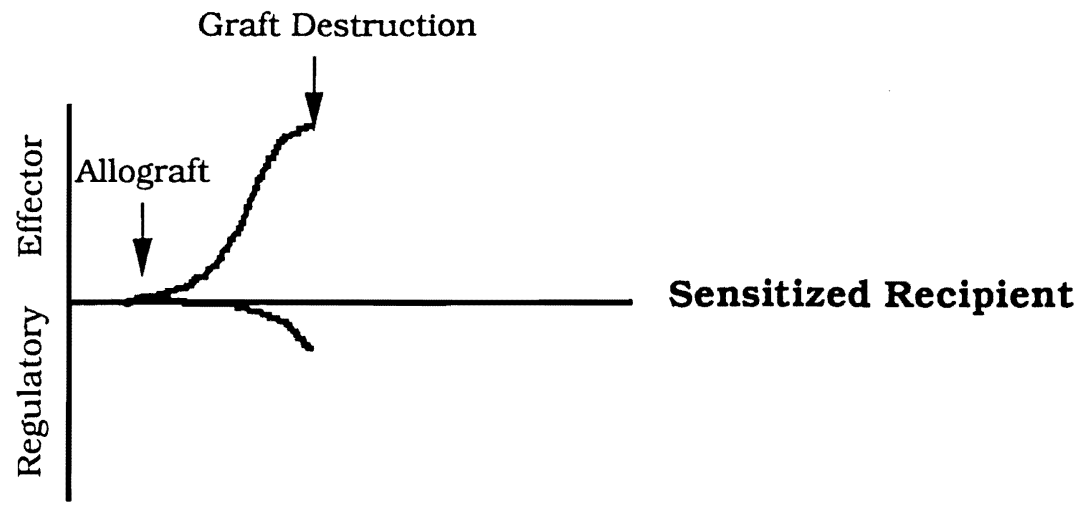

b)

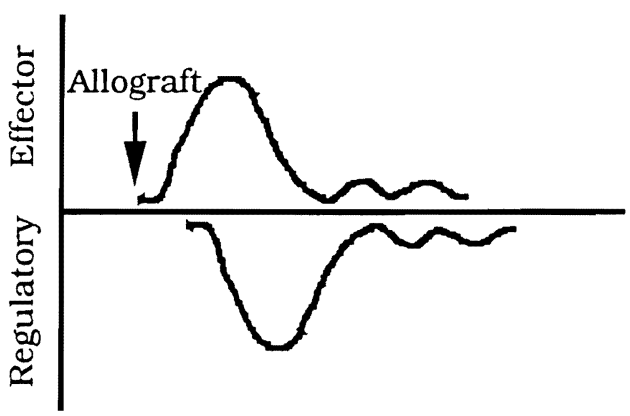

Naive Recipient

c)

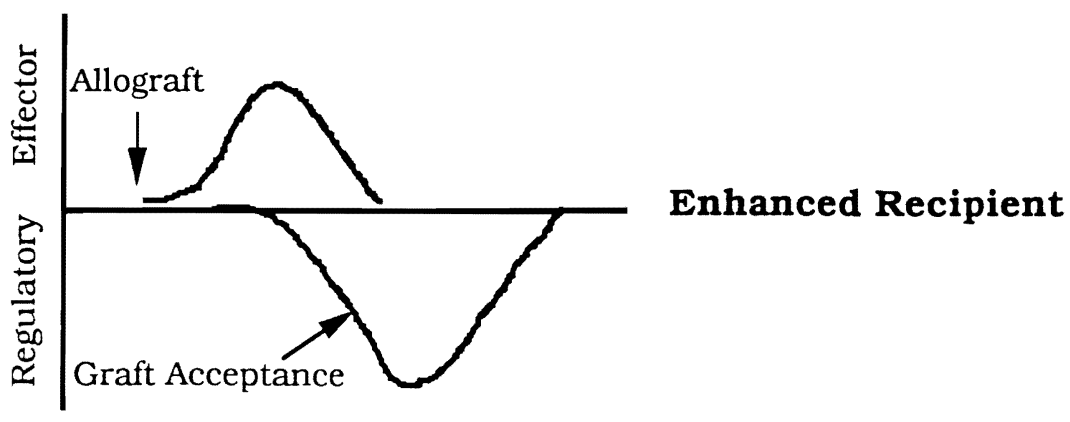

TIME

Figure 2. Schematic representation of an alloresponse of a sensitized (a); naive (b); and enhanced (c) recipients. Time post-transplant is represented on the Xaxis. The positive displacement on the Y-axis symbolizes the strength of the effector phase [i.e. rejection reaction]. The negative quadrant on the Y-axis represents the regulatory responses, which at present are poorly understood. 
alloreactive CD4+ $\mathrm{T}$ cells (anti, anti-donor MHC). SuciuFoca et al $(136,137)$ have provided direct evidence that such cells do indeed exist. They have shown that alloactivated $T$ cells develop idiotypic-like determinants, which elicit an autologous mixed lymphocyte response. This active response was shown to exhibit both specificity and memory in the primed lymphocyte test, which failed to exhibit secondary reactivity to autologous blasts primed against a different allospecificity $(136,137)$. Thus, the early brisk alloreaction provoked by the initial influx of donor cells into recipient lymphoid tissues, would begin to create an internal image of the donor in the recipient's immune system $(58,98,99)$.

The initial alloreaction also generates effector mechanisms, which have the potential to damage both the graft and mobile cells. If however, the graft and the migratory cells survive the effector response, the regulatory reaction described above, which is 180 degrees out of phase with the effector response (Figure 2), will eventually self-limit the rejection. Continual restimulation of the alloreaction, as would be seen with the survival of microchimeric hematolymphoid cells, would in turn also recruit the regulatory cells carrying the donorMHCi. Thus, alloreactive and auto-alloreactive MHCi regulatory reactions would be in a constant flux, resulting in a dynamic and at times unstable equilibrium (116). 
Meanwhile, the continued trafficking and participation of donor hematolymphoid cells in the recipient's immune system eventually would result in further erosion of the basis for alloreactivity $(58,143)$.

The explanation of donor specificity of allogeneic tolerance is obvious from our hypothesis. It is also clear how too much immunosuppression could prevent tolerance induction. Specificity is conferred by the presence of donor cells, or antigen maintaining the donor MHCi. Overly aggressive immunosuppression would not only inhibit the regulatory reactions, but also prevent donor cell division, which is particularly important during the formative stages of tolerance induction. Elegant studies by Russell et al $(144,145)$ illustrate these points.

They attempted to provoke destruction of an accepted kidney allograft in a "tolerant" recipient by infusion of syngeneic lymphoid cells, which had already been sensitized to the donor. Although they succeeded in causing graft rejection, it was only transient. The graft recovered and the recipient returned to a tolerant state $(144,145)$. Complete immunologic graft destruction required treatment with donor leukocytes (antigen), combined with cyclophosphamide pretreatment and/or continual BCG immunostimulation after delivery of the donor cells. These 
manipulations would either prevent or overwhelm respectively the regulatory responses.

Actively enhanced recipients, when subsequently challenged with an allograft, initially experience rejection that spontaneously resolves (146). This includes marked upregulation of donor MHC antigens (146), which has led several authors to conclude that the pretransplant blood transfusions are powerfully immunosuppressive. The active components in transfusions are known to be class II-bearing donor hematolymphoid cells (147-151). It is proposed that this form of pre-transplant conditioning (active enhancement) bolsters the regulatory reactions, outlined above and represent a "vaccination" or an indirect stimulation of donor MHCi cells. When the enhanced subject is subsequently challenged with an allograft, rejection is internally controlled before it is able to destroy the graft (Figure 2).

Wotherspoon et al (152) have provided more direct evidence that the alloreactive cell are capable of tolerance induction. They showed that cells capable of transferring allogeneic tolerance (or resistance to GVHD) also bear receptors for the tolerated alloantigen. Strelein et al (153) have summarized a similar experience in neonatal chimeras by showing the importance of "tolerogen-specific $T$ cells" in the maintenance of tolerance. Qin et al (154) 
provided evidence that tolerance could be transferred with $T$ cells across as many as four generation, a phenomenon he called "infectious" tolerance. We believe that idiotypic determinants on $\mathrm{T}$-cells provide a rational explanation for the above observations, and are similar to the reasoning behind using effector cell vaccination for preventing autoimmune allergic encephalitis (155) .

The association and importance of "autoimmune reactions" in the establishment and maintenance of allogeneic tolerance has been particularly well studied in neonatal chimeric mice (153,156-161). Briefly, chimeric donor $B$ and possibly other cells are thought to constantly stimulate recipient CD4+ cells, that show a TH2-type profile. These tolerogen-specific, TH2-type alloreactive CD4+ cells are unable to coordinate an effective rejection reaction, and in fact, inhibit the response through the secretion of IL-4 and possibly other TH2-type cytokines $(153,159,160)$. The elevated IL-4 also results in upregulation of class II MHC on the chimeric donor B-cells, B-cell hyperactivity and secretion of autoantibodies directed at DNA, smooth muscle cells and basement membrane constituents $(153,156-161)$.

Autoimmune reactions triggered by heavy metal injections or transient cyclosporine therapy share many features of the autoimmunity observed in the chronic GVHD 
models (162-166) described above. The BN rat is particularly sensitive to both of these syndromes, which appear to be dependent on autoreactive anti-Ia CD4+ T cells (162-165). Zhang et al (166) have shown that these autoreactive $\mathrm{T}$ cells are capable of prolonging heart allograft survival, and we have recently shown that BN recipients of LEW liver allografts also retain hematolymphoid chimerism for more than 300 days after liver transplantation, even without continual immunosuppressive therapy (58). More interestingly, BN recipients of LEW intestinal or liver allografts experience a lethal graft versus host disease, even when the percentage of donor cells is $<5 \%$ of the total lymphoid cell population (167). We currently are testing the hypothesis that although LEW donor cells are fewer in number, they receive assistance from "autoimmune" reactions precipitated by the alloreaction in the recipient's immune network.

The above hypothesis is similar to the hypotheses of van Rood et al (151) and Dorsch and Roser (168,169), although, there are key differences as well. Both of the groups just mentioned, stress the need for hematolymphoid chimerism and anti-idiotypic-like reactions. However, they also stress the necessity of MHC restriction and view the relationship between the two immune systems as one of antagonism. In contrast, we stress the possibility of effective collaboration across MHC barriers with "auto- 
reactivity" ultimately being responsible for graft

acceptance. Furthermore, we feel that the "autoimmune"-type reactions described in the preceding pages are likely part of the repertoire of a normally functioning immune network $(116-123)$.

It should be mentioned that shearer et al (170) and Hoffman et al (171) have used the concept of network focusing to explain the pan-immunologic deficit of the Acquired Immune Deficiency Syndrome (AIDS). They suggested that the combination of allogeneic lymphoid cells and HIV trigger chronic GVH and autoimmune reactions, which are internally directed against the CD4+ components of the immune network. The end result is overactivity of the MHCi system, which produces an immune defect that is far greater than would be expected if the virus alone were causing the disease.

From the preceding discussion, it would appear that specific allogeneic tolerance is something easily and reproducibly achieved. Such is not the case in clinical organ transplantation and therefore immunosuppressive protocols tend to be designed to completely abolish all alloreactivity. Our hypothesis would suggest that such an approach is not conducive to tolerance induction and eventual drug withdrawal. We now know that there are many 
more considerations to the induction of tolerance besides the elimination of rejection.

In fact, without alloactivation, there will be no tolerance. Effective immunosuppressants appear to function at least in part by permitting regulatory responses to occur, while protecting both the peripheralized donor hematolymphoid cells and graft from injury $(52-58,98,99)$. All the while, donor cells are assimilated into the recipient's immune network. In addition, FK 506 and cyclosporine change thymic physiology, by increasing the emigration into peripheral tissue of immature thymocytes $(172,173)$, and increasing the recruitment into the thymus of immature medullary dendritic cells (174).

The type of allograft may also play an important role in the induction of transplantation tolerance. For example, the liver contains a large number of natural killer cells, which can assist in donor hematolymphoid cell engraftment (175). The liver also is known to be intimately involved with regulation of hematopoietic stem cell activity in the bone marrow $(176,177)$. All of the considerations in the preceding two paragraphs could potentially influence the merging of two immune systems.

At present however, we do not know how to measure or control potentially beneficial regulatory responses. More 
importantly, we also do not know which factors dictate whether an alloantigen exposure will result in sensitization or tolerance. These two seemingly opposite reactions are obviously quite closely related. Nevertheless, empiric observations have shown that increasing the donor's immune system representation is advantageous for tolerance induction. Therefore, non-cytotoxic regimens are needed to enhance the survival or permit engraftment of donor hematolymphoid cells to accomplish immunologic redefinition of the recipient. Regardless of the specific approach, increasing attention to the network properties of immune systems will likely be required. 


\section{REFERENCES}

1. Snell GD. The homograft reaction. Ann Rev Microbiol $11: 439-458,1957$.

2. Steinmuller D. Immunization with skin isografts taken from tolerant mice. Science 158:127-129, 1967.

3. Steinman RM, Cohn ZA. Identification of a novel cell type in peripheral lymphoid organs of mice. I. Morphology, quantitation, tissue distribution. J Exp Med 137:1142-1162, 1973.

4. Steinman RM, Cohn ZA. Identification of a novel cell type in peripheral lymphoid organs of mice. II. Functional properties in vitro. J Exp Med 139:380-397, 1974.

5. Steinman RM, Lustig DS, Cohn ZA. Identification of a novel cell in peripheral lymphoid organs in mice. III. Functional properties in vivo. J Exp Med 139:1431-1445, 1974 .

6. Steinman RM. The dendritic cell system and its role in immunogenicity. Ann Rev Immunology 9:271-296, 1991. 
7. Talmage DW, Dart G, Radovich J, Lafferty KJ. Activation of transplant immunity; effect of donor leukocytes in thyroid allograft rejection. Science 191:385-387, 1976.

8. Lafferty KJ, Bootes A, Dart G, Talmage DW. Effect of organ culture in the survival of thyroid allografts in mice. Transplantation 22:138-149, 1976 .

9. Faustman D, Hauptfeld V, Lacy P, Davie J. Prolongation of murine islet allograft survival by pretreatment of islets with antibody directed to Ia determinants. Proc Natl Acad SCi USA 78:5156-5159, 1981.

10. Austyn JM, Steinman RM. The passenger leukocyte - a fresh look. Transpl Rev 2:139-176, 1988.

11. Fabre JW. Epidermal allografts. Immunology Letters $29: 161-166,1991$.

12. Billingham RE, Brent L, Medawar PB. Actively acquired tolerance of foreign cells. Nature 172:603-606, 1953.

13. Main JM, Prehn RT. Successful skin homografts after the administration of high dosage $\mathrm{X}$ radiation and homologous bone marrow. J Natl Cancer Inst 15:1023-1029, 1955. 
14. Slavin S, Strober S, Fuks Z, Kaplan HS. Induction of specific tissue transplantation tolerance using fractionated total lymphoid irradiation in adult mice. Long-term survival of allogeneic bone marrow and skin grafts. J Exp Med $146: 34-48,1977$.

15. Slavin S, Reitz B, Bieber CP, Kaplan HS, Strober S. Transplantation tolerance in adult rats using total lymphoid irradiation: permanent survival of skin, heart and marrow allografts. J Exp Med 147:700-707, 1978 .

16. Slavin S, Fuks Z, Weiss L, Morecki S. Mechanisms of tolerance in chimeric mice prepared with total lymphoid irradiation. ICN-UCLA Symp. Mol Cell Biol 17:383, 1980.

17. Ildstad ST, Sachs DH. Reconstitution with syngeneic plus allogeneic or xenogeneic bone marrow leads to specific acceptance of allografts or xenografts. Nature 307:168-170, 1984 .

18. Myburgh JA, Smit JA, Stark JH, Browde S. Total lymphoid irradiation in kidney and liver transplantation in the baboon: prolonged graft survival and alteration in $T$ cell subsets with low cumulative dose regimens. J Immunol $132: 1019-1025,1984$. 
19. Mayumi H, Himeno K, Tanaka K, Tokuda N, Fan J, Nomoto K. Drug induced tolerance to allografts in mice. XII. The relationships between tolerance, chimerism and graft-versushost disease. Transplantation 44:286-290, 1987.

20. Owen RD: Immunogenetic consequences of vascular anastomoses between bovine twins. Science 102:400-401, 1945 .

21. Anderson D, Billingham RE, Lampkin GH, Medawar PB: The use of skin grafting to distinguish between monozygotic and dizygotic twins in cattle. Heredity 5:379-397, 1952 .

22. Burnet FM, Fenner F: The Production of Antibodies.

2nd ed Melbourne, Macmillan 1949. pp: 1-142

23. Billingham $R$, Brent $L$, Medawar P: Quantitative studies on tissue transplantation immunity. III. Actively acquired tolerance. Philos Trans R Soc Lond (Biol) 239:357-412, 1956 .

24. Gatti RA, Meuwissen $H J$, Allen HD, Hong R, Good RA: Immunological reconstitution of sex-linked lymphopenic immunological deficiency. Lancet 2:1366-1369, 1968.

25. Thomas ED: Allogeneic marrow grafting - A story of man and dog. In Terasaki PI and Cecka JM, eds. Clinical Transplants, 1991 UCLA Press pp: $381-390$.

26. Billingham $\mathrm{R}$, Brent $\mathrm{L}$ : Quantitative studies on transplantation immunity. IV. Induction of tolerance in newborn mice and studies on the phenomenon of runt disease. Philos Trans R Soc Lond (Biol) 242:439-477, 1956. 
27. Billingham RE. Reactions of grafts against their hosts. Transplantation immunity works both way-hosts destroy grafts and grafts may harm hosts. Science 130:947-953, 1959.

28. Good RA: Immunologic reconstitution: The achievement and its meaning. Hospital Practice 1969, 4:41-47.

29. Rapaport FT, Bachvaroff RJ, Mollen N, Hirasawa H, Asano T, Ferrebee JW: Induction of unresponsiveness to major transplantable organs in adult mammals. Ann Surg 1979, $190: 461-473$.

30. Liegeois A, Charreire J, Brennan LB: Allograft enhancement induced by bone marrow cells. Surg Forum $25: 297-300,1974$.

31. Liegeois A, Escourrou J, Ouvre E, Charreire J: Microchimerism: A stable state of low-ratio proliferation of allogeneic bone marrow. Transplant Proc 9:273-276, 1977 .

32. Monaco AE, Wood ML, Russell PS: Studies of heterologous anti-lymphocyte serum in mice. III. immunologic tolerance and chimerism produced across the $\mathrm{H}-2$ locus with adult thymectomy and anti-lymphocyte serum. Annals of the New York Academy of Sciences. 129:190-209, 1966. 
33. Wood ML, Monaco AP, Gozzo JJ, Liegeois A: Use of homozygous allogeneic bone marrow for induction of tolerance with antilymphocyte serum: Dose and timing. Transplant Proc $3: 676-683,1971$.

34. Monaco AP, Wood ML, Maki T, Gozzo JJ: Post transplantation donor-specific bone marrow transfusion in polyclonal antilymphocyte serum-treated recipients: The optimal cellular antigen for induction of unresponsiveness to organ allografts. Transplant Proc 20:1207-1212, 1988.

35. Myburgh JA, Smit JA, Hill RRH, Browde S: Transplantation tolerance in primates following total lymphoid irradiation and allogeneic bone marrow injection. Transplantation $29: 405-408,1980$.

36. Myburgh JA, Smit JA, Browde S, Hill RRH:

Transplantation tolerance in primates following total lymphoid irradiation and allogeneic bone marrow injection. I. Orthotopic liver allografts. Transplantation 29:401404,1980 .

37. Saper V, Chow D, Engleman ED, Hoppe RT, Levin B, Collins G, Strober S: Clinical and immunological studies of cadaveric renal transplant recipients given total-lymphoid irradiation and maintained on low-dose prednisone. Transplantation 45:540-546, 1988 . 
38. Najarian JS, Ferguson RM, Sutherland DER, Slavin S, T Kim, Kersey T, Simmons RL: Fractionated total lymphoid irradiation as preparative immunosuppression in high-risk renal transplantation. Ann surg 196:442-452, 1982 .

39. Waer M, Vanrenterghem Y, Roels L, Ang KK, Bouillon R, Lerut T, Gruwez J, van der Schueren E, Vandeputte M, Michielsen P: Immunological and clinical observations in diabetic kidney graft recipients pretreated with totallymphoid irradiation. Transplantation 43:371-379, 1987.

40. Cortesini R, Molajoni ER, Berloco P, Bachetoni A, Cinti P, Trovati A, Sallusto F, Pretagostini, Iapelli M, Caricato M, Rossi M, Alfani D: Long-term follow-up of kidney grafts in high-risk patients under TLI and CsA therapy. Transplant Proc 21:1790-1792, 1989.

41. Myburgh AJ, Smit AJ, Meyers MA, Botha JR, Browde S, Thomson PD: Total lymphoid irradiation in renal transplantation. World J Surg 10:369-380, 1986.

42. Myburgh JA, Meyers AM, Thomson PD, Botha JR, Margolius L, Lakier R, Smit JA, Stark JH, Gray C: Total lymphoid irradiation-current status. Transplant Proc 21:826-828, 1989. 
43. Medawar PB: Transplantation of tissues and organs: introduction. Br Med Bull 21:97-99, 1965.

44. Weber RA, Cannon JA, Longmire WP: Observations on the regrafting of successful homografts in chickens. Ann Surg $139: 473-477,1954$.

45. Murray JE, Sheil AGR, Moseley R, Knight R, McGavic Dickinson J, Dammin GJ: Analysis of mechanism of immunosuppressive drugs in renal homotransplantation. Ann Surg 160:449-473, 1964 .

46 Starzl TE: Host-Graft Adaptation. In: Experience in Renal Transplantation WB Saunders Company, Philadelphia PA 1964. pp: 164-170.

47. Starzl TE: Efforts to Mitigate or Prevent Rejection. In: Experience in Hepatic Transplantation WB Saunders Company, Philadelphia PA 1969. pp: 203-206, 216-220, 226-233.

48. Levey RH: Immunological tolerance and enhancement: A common mechanism. Transplant Proc 3:41:48, 1971.

49. Murase N, Kim DG, Todo S, Cramer DV, Fung JJ, Starzl TE: FK 506 suppression of heart and liver allograft 
rejection II: The induction of graft acceptance in rat. Transplantation 50:739-744, 1990 .

50. Streilen JW: Neonatal tolerance of H-2 alloantigens. Procuring graft acceptance the "old-fashioned" way. Transplantation 52:1-10, 1991.

51. Eto M, Mayumi H, Nishimura, Maeda T, Yoshikai T, Nomoto $\mathrm{K}$ : Similarity and difference in the mechanisms of neonatally induced tolerance and cyclophosphamide-induced tolerance in mice J Immunol 147:2439-2446, 1991.

52 Starzl TE, Demetris AJ, Murase N, Ildstad S, Ricordi C, Trucco M: Cell migration, chimerism, and graft acceptance. Lancet 339:1579-1582, 1992 .

53. Starzl TE, Demetris AJ, Trucco M, Ramos H, Zeevi A, Rudert WA, Kocoua M, Ricordi C, Ildstad S, Murase N: Systemic chimerism in human female recipients of male livers. Lancet 340:876-877, 1992.

54. Starzl TE, Demetris AJ, Trucco M, Ricordi S, Ildstad S, Terasaki P, Murase N, Kendall RS, Kocoua M, Rudert WA, Zeevi A, Van Thiel D: Chimerism after liver transplantation for type IV glycogen storage disease and Type I Gaucher's disease. New Engl J Med 328:745-749, 1993. 
55. Starzl TE, Demetris AJ, Trucco M, Zeevi A, Ramos H, Terasaki P, Rudert WA, Kocova M, Ricordi C, Ildstad S, Murase N: Chimerism and donor specific nonreactivity 27 to 29 years after kidney allotransplantation. Transplantation $55: 1272-1277, \quad 1993$.

56. Starzl TE, Demetris AJ, Murase N, Thomson AW, Trucco M, Ricordi C: Cell chimerism permitted by immunosuppressive drugs is the basis of organ transplant acceptance and tolerance. Immunol Today 14(No.6):326-332, 1993.

57. Starzl TE, Demetris AJ, Trucco M, Murase N, Ricordi C, Ildstad S, Ramos H, Todo S, Tzakis A, Fung JJ, Nalesnik M, Rudert WA, Kocova M: Cell migration and chimerism after whole organ transplantation: The basis of graft acceptance. Hepatology $17(6): 1127-1152,1993$.

58. Demetris AJ, Murase N, Fujisaki S, Fung JJ, Rao AS, Starzl TE: Hematolymphoid cell trafficking, chimerism, and tolerance after liver, bone marrow, and heart transplantation: Rejection, GVHD and the merging of immune systems. J Exp Med

59. Qian S, Demetris AJ, Fu F, Li Y, Sun H, Lan G, Thai N, Dahman U, Murase N, Fung JJ, Starzl TE: Murine liver allograft transplantation: tolerance and donor cell chimerism. Hepatology 
60. Murase N, Demetris AJ, Kim DG, Todo S, Fung JJ, Starzl $\mathrm{TE}$ : Rejection of the multivisceral allografts in rats: $\mathrm{A}$ sequential analysis with comparison to isolated orthotopic small bowel and liver grafts. Surgery 108:880-889, 1990 .

61. Starzl TE, Marchioro TL, Porter KA, Taylor PD, Faris TD, Herrmann TJ, Hlad CJ, Waddell WR: Factors determining short-and long-term survival after orthotopic liver homotransplantation in the dog. Surgery 58:131-155, 1965. 62. Valdivia LA, Fung JJ, Demetris AJ, Starzl TE: Differential survival of hamster-to-rat liver and cardiac xenografts under FK 506 immunosuppression. Transplant Proc $1991 ; 23: 3269-3271$.

63. Garnier H, Clot J, Bertrand M, Camplez P, Kumlim A, Gorim JKP, LeGoaziou F, Levy R, Cordier G: Liver transplantation in the pig: surgical approach. Cr Acad Sci, Paris 260:5621-5623, 1965 .

64. Peacock JH, Terblanche J: Orthotopic homotransplantation of the liver in the pig. In: Read AE (ed.): The Liver, London, Butterworth \& Co., Ltd., 1967, $\mathrm{pp}: 333-336$. 
65. Calne RY, White HJO, Yoffa DE, Maginn RR, Binns RM, Samuel JR, Molina VP: Observations of orthotopic liver transplantation in the pig. Br Med J 2:478-480, 1967.

66. Zimmerman FA, Butcher GW, Davies HS, Brons G, Kamada N, Turel O: Techniques for orthotopic liver transplantation in the rat and some studies of the immunologic responses to fully allogeneic liver grafts. Transplant Proc 11:571-577, 1979.

67. Starzl TE, Ishikawa M, Putnam CW, Porter KA, Picache R, Husberg BS, Halgrimson CG, Schroter G: Progress in and deterrents to orthotopic liver transplantation, with special reference to survival, resistance to hyperacute rejection, and biliary duct reconstruction. Transplant Proc 6:129139,1974 .

68. Kamada N, Davies HFFS, Roser B: Reversal of transplantation immunity by liver grafting. Nature $292: 840-842,1981$.

69. Houssin D, Gugenheim J, Bellon B, Brunard M, Gigou M, Charra M, Crougneau S, Bismuth H: Absence of hyperacute rejection of liver allografts in hypersensitized rats. Transplant Proc 17:293-295, 1985 . 
70. Fung J, Makowka I, Tzakis A, Klintmalm G, Duquesnoy R, Gordon R, Todo S, Griffin M, Starzl TE: Combined liverkidney transplantation: Analysis of patients with preformed lymphocytotoxic antibodies. Transplant Proc 1988; 20 (Suppl. 1):88-91.

71. Calne RY, Sells RA, Pena JR, Davis DR, Millard PR, Herbertson BM, Binns RM, Davies DAL: Induction of immunological tolerance by porcine liver allografts. Nature $233: 472-474,1969$.

72. Valdivia L, Demetris AJ, Fung JJ, Celli S, Murase N, Starzl TE: Successful hamster to rat liver xenotransplantation under FK 506 immunosuppression induces unresponsiveness to hamster heart and skin. Transplantation $55: 659-661,1993$.

73. Hart DNJ, MCKenzie JL: Interstitial dendritic cells. Int Rev Immunol 6:128-149, 1990 .

74. Hart DNJ, Winearls CG, Fabre JW: Graft adaptation: studies on possible mechanisms in long-term surviving rat renal allografts. Transplantation 30:73-80, 1980 .

75. Batchelor JR, Welsh KI, Maynard A, Burgos H: Failure of long surviving, passively enhanced allografts to provoke T-dependent alloimmunity: I. Retransplantation of (AS X 
AUG) F1 kidneys into secondary AS recipients. J Exp Med $150: 455-464,1979$.

76. Lechler RI, Batchelor JR: Restoration of immunogenicity to passenger cell-depleted kidney allografts by the addition of donor-strain dendritic cells. J Exp Med 155:31-41, 1982 .

77. Marchioro TL, Rowlands DT Jr, Rifkind D, Waddell WR, Starzl TE, Fudenberg H: Splenic homotransplantation. Ann NY Acad Sci 120:626-651, 1964 .

78. Wakely E, Oberholser JH, Corry RJ: Elimination of acute grhd and prolongation of rat pancreas allograft survival with DST, cyclosporine, and spleen transplantation. Transplantation 49:241-245, 1990 .

79. Bitter-Suermann H, Save-Soderbergh JS: The course of pancreas allografts in rats conditioned by spleen allografts. Transplantation 26:28-34, 1978 .

80. Murase N, Demetris AJ, Matsuzaki T, Yagihasi A, Todo S, Fung J, Starzl TE: Long survival in rats after multivisceral versus isolated small bowel allotransplantation under FK 506. Surgery 110:87-98, 1991. 
81. Prop J, Kuijpers K, Petersen AH, Bartels HL,

Nieuwenhuis $\mathrm{P}$, Wildevuur $\mathrm{CRH}$ : Why are lung allografts more vigorously rejected than hearts? Heart Transplantation $4: 433-436,1985$.

82. Westra AL, Prop J, Kuijpers KC, Wildevuur CRH: A paradox in heart and lung rejection. Transplantation $49: 826-828,1990$

83. Iwaki Y, Starzl TE, Yagihashi A, Taniwaki S, Abu-Elmagd K, Tzakis A, Fung J, Todo S: Replacement of donor lymphoid tissue in human small bowel transplants under FK 506 immunosuppression. Lancet 337:818-819, 1991.

84. Murase N, Demetris AJ, Woo J, Furuya T, Nalesnik M, Tanabe M, Todo S, Starzl TE: Lymphocyte traffic and graftversus-host disease after fully allogeneic small bowel transplantation. Transplant Proc 23:3246-3247, 1991.

85. Murase N, Demetris A, Woo J, Tanabe M, Furuya T, Todo S, Starzl TE: Graft versus host disease (GVHD) after BN to LEW compared to LEW to BN rat intestinal transplantation under FK 506. Transplantation 55:1-7, 1993.

86. Nemlander A, Soots A, Willebrand EV, Husberg B, Hayry P: Redistribution of renal allograft responding leukocytes during rejection. II. Kinetics and specificity. J Exp Med $156: 1087-1100,1982$.

87. Larsen CP, Morris PJ, Austyn JM: Migration of dendritic leukocytes from cardiac allografts into host 
spleens. A novel route for initiation of rejection. J Exp Med 171:307-314, 1990 .

88. Demetris AJ, Qian S, Sun H, Fung JJ, Yagihashi A, Murase N, Iwaki Y, Gambrell B, Starzl TE: Early events in liver allograft rejection. Am J Pathol 138:609-618, 1991 .

89. Forbes RD, Parfrey NA, Gomersail M, Darden AG, Guttmann RD: Dendritic cell-lymphoid aggregation and major histocompatibility antigen expression during rat cardiac allograft rejection. J Exp Med 164:1239-1258, 1986.

90. van Schlifgaarde R, Hermans P, Terpstra JL, van Breda Vriesman PJC: Role of mobile passenger lymphocytes in the rejection of renal and cardiac allografts in the rat. Transplantation 29:209, 1989.

91. Hayry and Willebrand. Transplantation and Clinical Immunology. Volume 15, Immunosuppression. 15th International Course, Lyon, (eds., Touraine, Thaegen, Betuel, Brochier, Dubernard, Revillard, \& Triau). Excerpta Medica, Amsterdam, 1983.

92. von Willebrand E, Taskinen E, Ahonen J, Hayry P: Recent modifications in the fine needle asipration biopsy of human renal allografts. Transplant Proc 15:1195-1197, 1983 . 
93. Corry RJ, Winn HJ, Russell PS: Primary vascularized allografts of hearts in mice: The role of $\mathrm{H}-2 \mathrm{D}, \mathrm{H}-2 \mathrm{~K}$ and non-H-2 antigens in rejection. Transplantation 16:343-350, 1973 .

94. Russell PS, Chase CM, Colvin RB, Plate JMD: Kidney tranpslants in mice. An analysis of the immune status of mice bearing long-term G-2 incompatible transplants. J Exp Med 147:1449-1468, 1978 .

95. Benson MT, Buckley G, Jenkinson EJ, Owen JJ. Survival of deoxyguanosine treated fetal thymus allografts is prevented by priming with dendritic cells. Immunology $60(4): 593-596,1987$.

96. Demetris AJ, Murase N, Starzl TE. Donor dendritic cells in grafts and host lymphoid and non-lymphoid tissues after liver and heart allotransplantation under short term immunosuppression. Lancet 339:1610, 1992.

97. Srlwatanawongsa V, Davies HffS, Brons IGM, Aspinall R, Thiru S, Jamieson NV, Calne SRY. Continued presence of donor leukocytes in recipients of liver grafts. Transplant Proc 25:371-372, 1993 . 
98. Kroczek RA, Black CDV, Barbet J, Shevach EM. Mechanisms of action of cyclosporine $A$ in vivo. J Immunol. $139: 3597-3603,1987$.

99. Clerici M, Shearer GM. Differential sensitivity of human $T$ helper cell pathways by in vitro exposure to cyclosporine A. J Immunol 144:2480-2485, 1990.

100. Austyn JM, Kupiec-Weglinski JW, Hankins DF, Morris PJ. Migration patterns of dendritic cells in the mouse: Homing to $\mathrm{T}-\mathrm{cell}$ dependent areas of spleen, and binding with marginal zone. J Exp Med 167:646-651, 1988 .

101. Nieuwenhuis P, DeVries-Bos L, Opstelten D, Deenen GJ, Stet RJM, Rozing J, 1983. Lymphocyte migration across major histocompatibility barriers in splenectomized rats. Immunol Rev. $73: 53-70,1983$.

102. Austyn JM, Larsen CP. Migration patterns of dendritic leukocytes. Transplantation 49:1-7, 1990.

103. Roncarlo MG, Touraine JL, Banchereau J. Cooperation between major histcompatibility complex mismatched mononuclear cells from a human chimera in the production of antigen-specific antibody. J. Clin. Invest. 77:673-680, 1986 . 
104. Thomas J, Carver M, Cunningham P, Park K, Gonder J. Promotion of incompatible allograft acceptance in rhesus monkeys given posttransplant antithymocyte globulin and donor bone marrow. I. In vivo parameters and immunohistologic evidence suggesting microchimerism.

Transplantation 43:332-338, 1987 .

105. Roberts JP, Ascher NL, Lake J, Capper J, Purohit S, Garovoy M, Lynch R, et al. Graft versus host disease after liver transplantation in humans. A report of four cases. Hepatology 14:274-281, 1991 .

106. Collins RH, Anastasi J, Terstappen LWWM, Nikaein A, Feng J, Fay JW, Klintmalm G, stone MJ: Brief Report: Donor-derived long-term multilineage hematopoiesis in a liver-transplant recipient. New Engl J Med 328:762-765, 1993.

107. Comenzo ROL, Malachowski ME, Rohrer RJ, Freeman RB, Rabson A, Berkman EM. Anomalous ABO phenotype in a child after an ABO-incompatible liver transplantation. N. Engl. J. Med. 326:867-889, 1992 .

108. Monaco AP and Wood ML. Studies on heterologous antilymphocyte serum in mice. VII. Optimal cellular antigen for induction of immunologic tolerance with ALS. Transplant Proc 2:489-496, 1970 . 
109. Monaco AP, Wood ML, Maki T, Gozzo JJ. Post transplantation donor-specific bone marrow transfusion in polyclonal antilymphocyte serum-treated recipients. The optimal cellular antigen for induction of unresponsiveness to organ allografts. Transplant Proc. 20:1207-1212, 1988 .

110. Strelein JW, strome P, Wood PJ. Failure of in vitro assays to predict accurately the existence of neonatally induced H-2 tolerance. Transplantation 48:630-1989.

111. Mayumi H, Himeno K, Tokuda N, Fan JL, Nomoto K. Drug induced tolerance to allografts in mice. X Augmentation of split tolerance in murine combinations disparate at both $\mathrm{H}-2$ and Non-H-2 antigens by the use of spleen cells from donors preimmunized with recipient antigens. Immunobiol. 174:274291,1987 .

112. Wood KJ. Alternative approaches for the induction of transplantation tolerance. Immunology Letters 29:133-138, 1991.

113. Miller JFAP. Post-thymic tolerance to self antigens. Journal of Autoimmunity 5:27-35, 1992 . 
114. Ramsdell F, Fowlkes BJ. Maintenance of in vivo tolerance by persistence of antigen. Science 257:11301134,1992 .

115. Reyes J, Zeevi A, Ramos HC, Tzakis A, Todo S, Demetris AJ, Nour B, Nalesnik M, Trucco M, Abu-Elmagd K, Fung JJ, Starzl TE: The frequent achievement of a drug free state after orthotopic liver transplantation. Transplant Proc (In Press).

116. Coutinho A. Beyond clonal selection and network. Immuno Rev. 110:63-87, 1989 .

117. Perelson AS. Immune Network Theory. Immunol Rev. $110: 5-36,1989$

118. Hoffmann GW, Kion TA, Forsyth RB, Soga KG, CooperWillis A. In: Theoretical immunology, ed. Perelson AS. (Addison-Wesley. Redwood City, CA, pp. 291-319, 1988.

119. Hoffmann GW. In: Regulation of immune response dynamics, eds. Delisi, C. \& Hiernaux, J. (CRC, Boca Raton, FL). pp. 137-162, 1982 .

120. Hoffmann GW. In The Semiotics of cellular communication in the immune system, eds. Sercarz, E.E., 
Celada. F., Mitchiso, .AA. \& Tada, T. (Springer, New York), pp. $257-271,1988$

121. Cohen IR. The cognitive paradigm and the immunological homunculus. Immunology Today 13:490-494, 1992.

122. Perelson AS, Weisbuch G. Modeling immune reactivity in secondary lymphoid organs. Bulletin of Mathematical Biology. $\quad 54: 649-672,1992$.

123. De Boerts RJ, Segel LA, Perelson AS. Pattern formation in one- and two-dimensional shape-space models of the immune system. J Theor. Biol 155:295-333, 1992 .

124. Rolstad B, Benestad HB. Spontaneous alloreactivity of natural killer (NK) and lymphokine-activated killer (LAK) cells from athymic rats against normal haemic cells. NK cells stimulate syngeneic but inhibit allogeneic haemopoiesis. Immunol 74:86-93, 1991.

125. Vaage JT, Dissen E, Ager A, Fossum S, Rolstad B. Allospecific recognition of hemic cells in vitro by natural killer cells from athymic rats; evidence that allodeterminants coded for by single major histocompatibility complex haplotypes are recognized. Eur J Immunol 21:2167-2175, 1991 . 
126. Miller JFAP, Morahan G. Peripheral T Cell Tolerance. Ann Rev Immunol 10:31-69, 1992.

127. Nossal GJV. Immunologic tolerance: Collaboration between antigen and lymphokines. Science 245:147-153, 1989.

128. Matzinger $\mathrm{P}$, Guerder $\mathrm{S}$. Does $\mathrm{T}$ cell tolerance require a dedicated antigen presenting cell? Nature 338:74-76, 1989.

129. Russell PS: Modification of runt disease in mice by various means. In: Transplantation: Ciba Foundation Symposium (Wolstenholme CEW, Cameron MP, London J, Churchill A, eds), Little Brown and Co., Boston, MA 1962 $\mathrm{pp}: \quad 350-383$

130. Kappler JW, Roehm M, Marrack P. T cell tolerance by clonal elimination in the thymus. Cell 49:273-280, 1987.

131. Zinkernagel RM, Hengartner $\mathrm{H}$. T cell receptor V use predicts reactivity and tolerance to Mlsa-encoded antigens. Nature 332:40-45, 1988 .

132. Finberg, R, Burkakoff SJ, Cantor H, Benacerraf B. Biological significance of alloreactivity: T cells stimulated by Sendai virus-coated syngeneic cells 
specifically lyse allogeneic targets cells. Proc Natl Acad SCi USA 75:(10) 5145-5149, 1978.

133. Gaston JSH, Waer, M. Virus-specific MHC-restricted T lymphocytes may initiate allograft rejection. Immunol Today 6: 237-???, 1985.

134. Benacerraf, B. Significance and biological function of Class II MHC molecules. Am J Pathol 120:334-343, 1985.

135. Belligrau D, Wilson DB. Immunological studies of $\mathrm{T}$ cell receptors. J Exp Med 103-114.

136. Suciu-Foca N, Rohowsky C, Kung P, King DW. Idiotypelike determinants on human $\mathrm{T}$ lymphocytes alloactivated in mixed lympocyte culture. J Exp Med 156:283-288, 1982.

137. Suciu-Foca N, Rohowsky C, Kung P, Lewison A, Nicholson $\mathrm{J}$, Reemstsma K, King DW. MHC-specific idiotypes on alloactivated human $T$ cells: In vivo and in vitro studies. Transplant Proc XV:784-789, 1983.

138. Kimura H, Pickard A, Wilson DB. Analysis of $T$ cell populations that induce and mediate specific resistance to graft-versus-host disease in rats. J Exp Med 160:652-658, 1984 . 
139. Saito K, Tamura A, Narimatsu H, Tadakuma T, Nagashima M. Cloned auto-Ia-reactive $T$ cells elicit lichen planuslike lesion in the skin of syngeneic mice. Journal of Immunology 137:2485-2495, 1986 .

140. Sainis K, Datta SK. CD4+ T cell lines with selective patterns of autoreactivity as well as CD4- CD8- T helper cell lines augment the production of idiotypes shared by pathogenic anti-DNA autoantibodies in the NZB $X$ SWR model of lupus nephritis. Journal of Immunology 140:2215-2224, 1988 .

141. Pelletier L, Pasquier R, Rossert J, Vial MC, Mandet C, Druet $\mathrm{P}$. Autoreactive $\mathrm{T}$ cells in mercury-induced autoimmunity. Journal of Immunology 140:750-754, 1988 .

142. Cornacchia E, Golbus J, Maybaum J, Strahler J, Hanash S, Richardson B. Hydralazine and procainamide inhibit $\mathrm{T}$ cell DNA methylation and induce autoreactivity. Journal of Immunology 140:2197-2200, 1988

143. Palathumpat V, Sobis H, Vandeputte M, Michielsen P, Waer $M$. Induction of mixed lymphocyte reaction nonresponsiveness after chimeric thymus transplantation. Transplant Int 3:217-221, 1990 .

144. Russell PS, Chase CM, Colvin RB, Plate JMD. Kidney transplants in mice. An analysis of the immune status of 
mice bearing long-term, $\mathrm{H}-2$ incompatible transplants. J Exp Med $147(5): 1449-1468,1978$.

145. Russell PS, Chase CM, Colvin RB, Plate JMD. Induced immune destruction of long-surviving, H-2 incompatible kidney transplants in mice. J Exp Med 147(5):1469-1486, 1978 .

146. Armstrong $\mathrm{HE}$, Botton EM, MCMillan I, Spencer SC, Bradley JA. Prolonged survival of actively enhanced rat renal allografts despite accelerated cellular infiltration and rapid induction of both class I and class II MHC antigens. J. Exp. Med. 164:891-907, 1987.

147. Opelz G, Mickey MR, Terasaki PI: Blood transfusions and unresponsiveness to HL-A. Transplantation 16:649-656, 1973 .

148. Fabre JW, Morris PJ: Dose response studies in passive enhancement of rat renal allografts. Transplantation $15: 397-403,1973$.

149. Bradley JA. The blood transfusion effect: experimental aspects. Immunol Lett 29:127-132, 1991.

150. de Waal LP, van Twuyver E. Blood transfusion and allograft survival: Is mixed chimerism the solution for 
tolerance induction in clinical transplantation? Immunol $10: 417-425,1991$

151. van Rood JJ, Claas FHJ. The influence of allogeneic cells on the human $\mathrm{T}$ and $\mathrm{B}$ cell repertoire. Science $248: 1388-1393,1990$

152. Wotherspoon JS, Dorsch SE. Graft-versus-host resistance induced by tolerant cell populations. Transplantation 47:528-532, 1989 .

153. Strelein JW, Levy RB, Ruiz P, Matriano J, Socarras S. Multiple mechanism induce and maintain neonatal transplantation tolerance. Transplant Sci. 3:11-16, 1993 .

154. Qin S, Cobbold SP, Pope H, Elliott J, Kioussis D, Davies J, Waldmann H. "Infectious" transplantation tolerance. Science 259:974-977, 1993.

155. Herber-Katz E, Acha-Orbea H: The V-region disease hypothesis: evidence from autoimmune encephalomyelitis. Immunology Today 10:164-169, 1989 .

156. Goldman M, Feng HM, Engers H, Hochman A, Louis J, Lambert PH. Autoimmunity and immune complex disease after neonatal induction of transplantation tolerance in mice. Journal of Immunology 131:251-258, 1983 . 
157. Merino J, Schurmans S, Luzuy S, Izui S, Vassalli P, Lambert PH. Autoimmune syndrome after induction of neonatal tolerance to alloantigens: effects of in vivo treatment with anti-T cell subset monoclonal antibodies. 139:1426-1431, 1988.

158. Goldman M, Abramowicz D, Lambert P, Vandervorst P, Bruyns C, Toussaint C. Hyperactivity of donor B cells after neonatal induction of lymphoid chimersim in mice. Clin Exp Immunol $72: 79-83,1988$.

159. Schurmans S, Heusser CH, Qin HY, Merino J, Brighous G, Lambert $\mathrm{PH}$. In vivo effects of anti-IL-4 monoclonal antibody on neonatal induction of tolerance and or an associated autoimmune syndrome. Journal of Immunology 145:2465-2473, 1990 .

160. Abramowicz D, Vandervorst P, Bruyns C, Doutrelepont JM, Vandenabeele P, Goldman M. Persistence of anti-donor allohelper $\mathrm{T}$ cells after neonatal induction of allotolerance in mice. Eur J Immunol 20:1647-1653, 1990.

161. Guery JC, Tournade V, Pelletier L, Druet O, Druet P. Rat anti-glomerular basement membrane antibodies in toxininduced autoimmunity and in chronic graft vs host reaction share recurrent idiotypes. Eur J Immunol 20:101-105, 1990. 
162. Tournade $\mathrm{H}$, Pelletier L, Pasquier R, Vial MC, Mandet C, Druet P. Graft-versus-host reactions in the rat mimic toxin-induced autoimmunity. Clin Exp Immunol 81:334-338, 1990.

163. Pelletier L, Pasquier R, Guetttier C, Cecile Vial M, Mandet $\mathrm{C}$, Nochy $\mathrm{D}$, Basin H, Druet $\mathrm{P}$. HgCl2 induces $\mathrm{T}$ and $\mathrm{B}$ cells to proliferate and differentiate in BN rats. Clin Exp Immunol 71:336-342, 1988 .

164. Aten J, Veninga A, De Heer E, Rozing J, Nieuwenhuis P, Hoedemaeker PJ, Weening JJ. Susceptibility to the induction of either autoimmunity or immunosuppression by mercuric chloride is related to the major histocompatibility complex Class II haplotype. Eur J Immunol 21:611-616, 1991.

165. Goldman M, Druet P, Gleichmann E. TH2 cells in systemic autoimmunity: insights from allogeneic diseases and chemically-induced autoimmunity. Immunology Today 12:223$227,1991$.

166. Zhang H, Hortitz L, Fischer AC, Laulis M, Colombani PM, Hess AD. Adoptive transfer of cyclosporine-induced MHC class II autoreactive cells prolongs heart allograft survival. Transplant Sci 3:17-19, 1993. 
167. Tanabe M, Murase N, Demetris AJ, Hoffman RA, Nakamura K, Fujisaki S, Galvao FHF, Todo S, Fung J, Starzl TE: The influence of donor and recipient strains in isolated small bowel transplantation in rats. Gastroenterology (In Press).

168. Dorsch S, Roser B. Suppressor cells in transplantation tolerance. Transplantation 33:518-524, 1982 .

169. Dorsch S, Roser B. Suppressor cells in transplantatio tolerance II. Transplantation 33:525-529, 1982 .

170. Shearer GM. Allogeneic leukocytes as a possible factor in induction of AIDS in homosexual men. $\mathrm{N}$ Engl $\mathrm{J}$ Med $308: 223-224,1983$.

171. Hoffmann GW, Kion TA, Grant MD. An idiotypic network model of AIDS immunopathogenesis. Proc Natl Acad Sci $88: 3060-3064,1991$.

172. Hosseinzadeh H, Goldschneider I. Demonstration of large-scale migration of cortical thymocytes to peripheral lymphoid tissues in cyclosporine A-treated rats. J Exp Med (in press).

173. Hosseinzadeh H, Goldschnedier I. Recent thymic emigrants in the rat express a unique antigenic phenotype 
and undergo post-thymic maturation in peripheral lymphoid tissues. J Immunol 150:1670-1679, 1993 .

174. de Waal EJ, Rademakers LH, Schuurman HJ, van Lovesen H. Interdigitating cells in the rat thymus during cyclosporin A treatment: ultrastructural observations.

Thymus 20:163-170.

175. Lafreniere R, Borkenhagen K, Bryant LD, Anton AR, Chung A, Poon MC. Analysis of liver lymphoid cell subsets pre- and post-in vivo administration of human recombinant interleukin 2 in a C57BL/6 murine system. Cancer Research $50: 1658-1666,1990$.

176. Sakamoto T, Saizawa T, Mabuchi A, Norose Y, Shoji T, Yokomuro $\mathrm{K}$. The liver as a potential hematolymphoid organ examined from modifications occurring in the systemic and intrahepatic hematolymphoid system during liver regeneration after partial hepatectomy. Regional Immunology 4:1-11, 1992 .

177. Sakamoto T, Maabuchi A, Kuriya SI, Sudo T, Aida T, Asano G, Shoji T, Yokomuro K. Production of granulocytemacrophage colony-stimulating factor by adult murine parenchymal liver cells (hepatocytes). Regional Immunology $3: 260-267,1990$. 